\title{
KONSELING PUBLIK MUSIKAL TOTOBUANG PADA KOMUNITAS HAUR DI DUSUN KUSU-KUSU SEREH, AMBON
}

\author{
${ }^{1}$ Alfrin Ririne dan ${ }^{2}$ Jacob Daan Engel \\ ${ }^{1}$ Magister Sosiologi Agama UKSW \\ 1Email: ririnealfrin@gmail.com
}

\begin{abstract}
Research this aim study meaning, implementation, and origin musical ritual totobuang in community haur in Hamlet Kusu-kusu Sereh Ambon, develop musical ritual totobuang from perspective counseling the community. Research this motivated by context social the community in Hamlet Kusu-Kusu Sereh Ambon which has inequality social concerning level economy. Method research used research qualitative with approach descriptive analytical. Required data obtained with technique Interview deep no Supported structured with observation / observation participation use support data analysis. While in technique taking sample, researcher use purposive and snowball technique. The theory used in research this is theory counseling community, social justice counseling, and ritual theory. From the results findings concerning musical rituals totobuang there is spiritual values namely value harmony, value potency self, value economy creative and value innovation yourself. From the fourth The spiritual values give birth a base philosophical that is humanizing life. Living capable empower individual or group so that they could give contribution good for self alone, others or the community. Researcher too recommend for research advanced in development writing this as effectiveness of musical ritual counseling models totobuang who can made as a approach counseling new in the community .
\end{abstract}

Word Key : musical ritual totobuang , counseling community, social justice counseling

\begin{abstract}
ABSTRAK
Penelitian ini bertujuan mengkaji pemaknaan, pelaksanaan, dan asal-usul ritual musikal totobuang dalam komunitas haur di Dusun Kusu-kusu Sereh, Ambon, mengembangkan ritual musikal totobuang dari perspektif konseling masyarakat. Penelitian ini dimotivasi oleh konteks sosial masyarakat di Dusun Kusu-Kusu Sereh, Ambon yang memiliki ketidaksetaraan sosial menyangkut tingkat perekonomian. Metode penelitian yang dipergunakan penelitian kualitatif dengan pendekatan deskriptif analitis. Data-data yang diperlukan diperoleh dengan teknik wawancara mendalam tidak terstuktur yang didukung dengan pengamatan/observasi partisipasi guna mendukung analisis data. Sedangkan dalam teknik pengambilan sampel, peneliti menggunakan teknik purposive dan snowball. Teori yang digunakan dalam penelitian ini adalah teori konseling masyarakat, konseling social justice, dan teori ritual. Dari hasil temuan-temuan menyangkut ritual musikal totobuang terdapat nilai-nilai spiritual yakni nilai kerukunan, nilai potensi diri, nilai ekonomi kreaktif dan nilai inovasi diri. Dari keempat nilai spiritual tersebut melahirkan sebuah landasan filosofis yakni hidup yang memanusiakan. Hidup yang mampu memberdayakan individu maupun kelompok sehingga mereka dapat memberikan kontribusi baik untuk diri sendiri,orang lain maupun masyarakat. Peneliti juga merekomendasikan untuk penelitian lanjutan dalam pengembangan tulisan ini seperti efektivitas model konseling ritual musikal totobuang yang dapat dijadikan sebagai sebuah pendekatan konseling baru dalam masyarakat.
\end{abstract}

Kata Kunci: ritual musikal totobuang, konseling masyarakat, konseling social justice

\section{PENDAHULUAN}

Dalam penulisan ini, saya akan mengkaji tentang ritual musikal totobuang sebagai konseling publik untuk komunitas haur di Dusun
Kusu-kusu Sereh, Ambon . Ritual musikal totobuang merupakan sebuah tradisi dan kebiasaan yang telah dilakukan secara turuntemurun oleh suatu komunitas yang mendiami

Dialektika: Jurnal Pemikiran Islam dan IImu Sosial | Vol. 12, No. 02 | 2019 | Page | 168 E-ISSN: 2685-791X P-ISSN: 1858-3679 
Dusun Kusu-kusu Sereh Ambon. Ritual musikal totobuang mengandung nilai-nilai spiritual antara lain nilai kerukunan sebagai bentuk dari pemberdayaan sosial yang seimbang dan setara, nilai potensi diri sebagai bentuk pencapaian integritas diri dalam masyarakat, nilai ekonomi kreatif sebagai bagian dari pencapaian kesetaraan hidup dalam masyarakat dan nilai inovasi diri sebagai bagian dari kesejahteraan hidup dalam masyarakat. Nilai-nilai spiritual tersebut melahirkan sebuah landasan filosofis yakni "hidup yang memanusiakan". Hidup yang memanusiakan mengandung arti bahwa proses konseling yang terjadi tidak hanya sebatas membuat klien keluar dari penderitaan hidup tetapi dapat membuat klien mampu mengembangkan berbagai potensi diri yang pada akhirnya memberikan kontribusi bagi diri sendiri, orang lain maupun masyarakat. Landasan filosofis tersebut dapat dijadikan landasan hidup yang mengarah pada kesetaraan dan kesejahteraan hidup dalam masyarakat.

Konteks masyarakat di Dusun Kusu-kusu Sereh yang beragam dan berbeda seringkali memunculkan relasi dan interaksi sosial yang dibangun tidak seimbang dan tidak merata baik menyangkut perbedaan budaya, strata sosial maupun tingkat perekonomian. Hal tersebut yang mengakibatkan individu maupun kelompok merasa terpinggirkan dalam masayarkat. Penelitian tentang penggunaan musik tradisional atau musik lokal dan pendekatan konseling pastoral telah diteliti oleh peneliti terdahulu. ${ }^{1}$

1 Tulisan NDN Botter pada tahun 2015 dengan judul Studi terhadap Penggunaan Alat Musik di Jemaat GPM Soya Klasis Pulau Ambon; Yuditha Gianti Tildjuir pada tahun 2017 dengan judul Ain ni Ain sebagai Pendekatan Konseling Perdamaian Berbasis Budaya; Jandry Lawalata pada tahun 2017 dengan judul Pela Gandong sebagai Konseling Orang Basudara dan Agen Perdamaian Konflik Islam-Kristen di Ambon
Para peneliti terdahulu lebih mengkaji mengenai musik musik tradisional dalam penggunaan musik gereja di Maluku, tidak mengarah kepada proses pemberdayaan. Penelitian mengenai konseling pastoral hanya berpusat pada konseling yang berbasis budaya sebagai sarana perdamaian. Setelah saya menelaah hasil-hasil penelitian di Maluku, saya tidak menemukan tulisan mengenai konseling publik dan ritual musikal totobuang sebagai bagian dari pemberdayaan individu maupun kelompok. ${ }^{2}$

Dusun Kusu-kusu Sereh merupakan salah satu bagian petauanan dari negeri Urimessing yang terletak dikecamatan Nusaniwe, Ambon. Kehidupan sosial masyarakat setempat begitu beragam dengan pola interaksi sosial, budaya, strata sosial dan tingkat perekonomian yang berbeda. Penghargaan akan budaya lokal masih terus dijaga dan dilestarikan oleh komunitas setempat. Setiap manusia atau masyarakat yang hidup bersama dalam satu komunitas tentu memiliki kebudayaan yang mengakar dalam kehidupannya dari generasi ke generasi. Budaya sendiri memiliki makna-makna tersendiri dalam kehidupan seperti yang dikemukakan oleh Geertz yaitu kebudayaan adalah sesuatu yang dengannya kita memahami dan memberi makna pada hidup kita. ${ }^{3}$ Fungsi sistem budaya adalah menata dan memantapkan tindakan-tindakan serta tingkah laku manusia. ${ }^{4}$

Penghargaan akan budaya dan tradisi lokal ini masih dilakukan oleh sebuah komunitas yang terdapat di Dusun Kusu-kusu Sereh yaitu

\footnotetext{
${ }^{2}$ Hasil Pencarian di perpustakan dan Arsip Daerah Provinsi Maluku, Perpustakaan Universitas Kristen Indonesia Maluku, dan Perpustakaan Wilayah Propinsi Maluku

3 Bernard T. Adeney. 2000. Etika sosial Lintas Budaya. Jogjakarta: Kanisius. H. 19.

4 Jacobus Ranjabar. 2013. Sistem Sosial Budaya Indonesia Suatu Pengantar. Bandung: Alfabeta. H. 9.
} 
komunitas haur totobuang. Komunitas tersebut melakukan ritual musikal totobuang sebagai upaya untuk pemberdayaan ekonomi yang berkualitas dan melalui ritual tersebut nilai-nilai kerukunan, nilai potensi diri, nilai ekonomi kreaktif dan nilai inovasi diri dapat dijadikan sebagai landasan hidup dalam suatu masyarakat mengingat strata sosial dan tingkat perekonomian yang berbeda yang seringkali menimbulkan ketidaksetaraan dalam masyarakat menyangkut kedudukan, peran dan kontribusi yang diberikan dalam masyarakat.

Ritual musikal totobuang yang dijadikan sebagai wadah pengembangan dan pemberdayaan potensi diri untuk komunitas haur totobuang ini dapat dikaji dalam perspektif konseling masyarakat, dan konseling social justice yang memiliki tujuan utama yaitu membawa orangorang atau kelompok dalam sebuah masyarakat keluar dari keterpurukan hidup dan dapat membuat orang diberdayakan untuk hidup yang memanusiakan sesama manusia. Engel menjelaskan konseling menjadi penting untuk membantu masyarakat dalam mengembangkan potensi dan pengetahuan masyarakat dalam menyelesaikan masalah. Ia juga mengemukakan bahwa konseling merupakan suatu upaya untuk memanusiakan sesama manusia. Dalam upaya memanusikan itulah, terkandung makna pemberdayaan yang menjadi tujuan utama suatu proses pendampingan dan konseling yang dilakukan. Dengan itu, konseling adalah suatu proses pertolongan yang membuat orang diberdayakan untuk hidup yang menghidupkan dan memanusiakan sesama manusia. Itu berarti konseling tidak sekadar membawa orang keluar dari keterpurukan dan penderitaan hidup, tetapi mengembangkan potensi-potensi yang dimiliki untuk memberdayakan dirinya dan orang lain, bahkan masyarakat. $^{5}$

Pemberdayaan diarahkan guna meningkatkan ekonomi masyarakat secara produktif sehingga mampu menghasilkan nilai tambah yang tinggi dan pendapatan yang lebih besar. Ekonomi masyarakat adalah segala kegiatan ekonomi dan upaya masyarakat untuk memenuhi kebutuhan hidupnya (basic need) yaitu sandang, pangan, papan, kesehatan dan pendidikan. Dengan demikian dapat dipahami bahwa pemberdayaan ekonomi masyarakat merupakan satu upaya untuk meningkatkan kemampuan atau potensi masyarakat dalam kegiatan ekonomi guna memenuhi kebutuhan hidup serta meningkatkan kesejahteraan mereka dan dapat berpotensi dalam proses pembangunan nasional. ${ }^{6}$ Proses pemberdayaan ekonomi dilakukan dengan tujuan untuk menciptkan masyarakat yang sejahterah dan setara.

Menurutnya Ratts Manivong.J dan Paul B. Pedersen, Tujuan social justice adalah memberdayakan semua individu, terlepas dari latar belakang mereka sehingga mereka dapat mengembangkan pengetahuan dan keterampilan untuk mencapai potensi penuh mereka. Konselor social justice menyadari bahwa masalah klien dapat dikaitkan dengan struktur yang menindas. Dengan demikian, baik konselor maupun klien secara aktif terlibat dalam proses mengeksplorasi dan mendapatkan pengetahuan tentang

5 J.D.Engel. 2018. Konseling Masalah Masyarakat. Yogyakarta:Kanisius. H. 2

${ }^{6}$ Daniel Sukalele, "Pemberdayaan Masyarakat Miskin di Era Otonomi Daerah", dalam wordpress.com/about/pemberdayaan-masyarakat-miskin-diera-otonomi-daerah diakses tgl. 27 Agustus 2018 
bagaimana struktur sosial mempengaruhi perkembangan klien. ${ }^{7}$

Berdasarkan pemaparan latar belakang di atas, dengan melihat nilai-nilai spiritual yang terkandung di dalam ritual musikal totobuang dan juga berbagai realita yang terjadi dalam kehidupan bermasyarakat di Dusun Kusu-kusu Sereh Ambon maka penulis ingin mengkaji ritual musikal totobuang sebagai pendekatan konseling publik untuk komunitas haur. Dengan demikian rumusan pertanyaan penelitian adalah Bagaimana ritual musikal totobuang dikembangkan sebagai konseling publik untuk komunitas haur di Dusun Kusu-kusu Sereh, Ambon? Rumusan masalah tersebut dijabarkan dalam beberapa pertanyaan pokok penelitian, yaitu: pertama, Bagaimana pemahaman dan pelaksanaan ritual musikal totobuang dalam komunitas Haur di Dusun Kusu-kusu Sereh, Ambon? Kedua, Bagaimana ritual musikal totobuang dikembangkan menjadi konseling publik untuk komunitas haur di Dusun Kusu-kusu Sereh Ambon?

Artikel ini mendeskripsikan dan menganalisis ritual musikal totobuang dapat dikembangkan sebagai konseling publik untuk komunitas haur. Tujuan penelitian ini juga dijabarkan dalam beberapa tujuan pokok penelitian, yaitu pertama, mendeskripsikan pemahaman dan pelaksanaan ritual musikal totobuang dalam komunitas haur di Dusun Kusukusu Sereh, Ambon, kedua, mendeskripsikan dan menganalisis ritual musikal totobuang tersebut dapat dikaji dari perspektif konseling publik .

\footnotetext{
${ }^{7}$ Manivong J. Ratts, Paul B Pedersen, Counseling for Multiculturalism and Social Justice, 28
}

\section{Metode}

Mengacu pada rumusan masalah dan tujuan penelitian yang hendak dicapai maka metode penelitian yang peneliti gunakan dalam penelitian ini adalah deskriptif analitis yakni penelitian yang berusaha menggambarkan atau melukiskan keadaan subjek yang diteliti. Setelah data diperoleh, kemudian data-data tersebut dianalisis dan diinterpretasi atau penafsiran data-data tersebut. ${ }^{8}$ Pendekatan yang di pakai dalam penelitian ini adalah pendekatan kualitatif yaitu pendekatan penelitian yang menyajikan data dalam bentuk kata-kata, sehingga tidak menekankan pada angka. Pendekatan kualitatif berusaha untuk menemukan dan mendeskripsikan makna atau data dibalik yang teramati. ${ }^{9}$

Penelitian ini dilakukan di Dusun Kusu-kusu Sereh, Ambon. Pengumpulan data dilakukan dengan wawancara dan observasi. Wawancara merupakan teknik pengumpulan data yang dilakukan secara berhadapan dengan informan sehingga dapat memperoleh informasi yang leluasa. Pertanyaan-pertanyaan yang diajukan haruslah pertanyaan yang bersifat terbuka dan tidak terstruktur yang dapat membuka pikiran informan untuk memberikan pendapat. ${ }^{10}$ Wawancara ini pun bermaksud mengumpulkan keterangan tentang kehidupan manusia dalam suatu masyarakat serta pendirian-pendirian mereka.

Pemilihan sampel penelitian menggunakan Snowball sampling dan Purposive sampling.

8 Winarno Surakhmad,. 1985. Pengantar Penulisan Ilmiah : Dasar Metode dan Teknik. Bandung : Tarsito. h.139

${ }^{9}$ Sugiyono. 2012. Metode Penelitian Kombinasi. Bandung: Penerbit Alfabeta. H. 15.

i0 John W. Creswell. 2010. Reseacrh Design: Pendekatan Kualitatif, Kuantitatif, dan Mixed. Yogyakarta: Pustaka Pelajar. h. 267. 
Menurut Sugiyono, Snowball sampling ${ }^{11}$ adalah teknik pengumpulan sampel yang mula-mula jumlahnya kecil, kemudian membesar. Dalam pengembalian data, dipakai beberapa orang untuk menjadi sumber data atau informan tetapi kalau merasa data yang diberikan belum lengkap, maka bisa dicari data tambahan melalui orang lain. Maka sumber data atau informan yang dipakai adalah beberapa orang dari masyarakat Dusun Kusu-kusu Sereh yang dianggap bisa mewakili pemahaman dari masyarakat yang nantinya bisa berkembang. Kemudian, pengambilan sampel data untuk melengkapi atau sebagai data informan yang pertama, maka dipakailah Purposive sampling. Menurut Sugiyono, Purposive sampling ${ }^{12}$ adalah teknik pengambilan sampel sumber data dengan pertimbangan tertentu. Pertimbangan tertentu ini, misalnya orang tersebut yang dianggap paling tahu tentang apa yang kita harapkan, atau mungkin dia sebagai penguasa sehingga akan memudahkan peneliti menjelajahi obyek atau situasi sosial yang diteliti. Dalam pengertian data yang sudah didapatkan pertama dikolaborasikan dengan data yang didapatkan dari orang yang dianggap lebih tahu dalam hal ini Informan yang dipilih adalah ketua komunitas haur, anggota-anggota haur totobuang, tokoh-tokoh adat, tokoh gereja (pendeta dan majelis jemaat). Kemudian teknik pengumpulan data berikutnya yaitu obeservasi. observasi adalah pengamatan dan pencatatan yang sistematis terhadap gejala-gejala yang diteliti. Jenis observasi yang dipakai yaitu observasi partisipasi sebagian yaitu dengan cara mengikuti sebagian dari kehidupan responden sesuai dengan data yang diinginkan

${ }^{11}$ Sugiyono. 2012. Metode Penelitian Kombinasi. Bandung: Penerbit Alfabeta. H. 127

${ }^{12}$ Sugiyono. 2013. Metode Penelitian Kuantitatif, Kualitatif dan R\&D. Bandung: Alfabeta. H. 218-219.

\section{LITERATUR REVIEW}

\section{Konseling masyarakat}

Konseling menjadi penting untuk membantu masyarakat dalam mengembangkan potensi dan pengetahuan masyarakat dalam menyelesaikan masalah. Keterbatasan masyarakat untuk memperoleh pengetahuan dan memanfaatkan konseling, menimbulkan berbagai fenomena masalah masyarakat. Konseling memungkinkan masyarakat mengembangkan bakat dan minat, serta memperoleh kesempatan untuk mengentaskan permasalahan yang dihadapi. ${ }^{13}$ Konseling berasal dari Bahasa Inggris to counsel yang berarti memberi arahan dan memberi nasehat. Tokoh yang melakukan proses konseling disebut konselor. Dalam pemahaman ini maka dalam proses konseling menempatkan konselor ke dalam relasi bersama dengan konseli. Selanjutnya proses konseling hanya dapat dibangun jika konselor menganggap konseli itu sangat berharga bukan sekedar dikasihani tetapi dicintai. Sehingga dalam proses konseling dimana terciptanya relasi atau hubungan yang harmonis orang dimungkinkan dapat mengalami kedamaian dan kebahagaiaan. ${ }^{14}$

Keefektifan konseling bergantung pada banyak faktor yang terpenting adalah relasi satu sama lain, dan saling mengerti antara konselor dan klien. Membangun hubungan yang baik saat proses konseling berlangsung agar konselor dapat memahami budaya yang dimiliki kliennya salah satu sikap kunci yang ada dalam diri konsleor adalah empati. Konselor yang memiliki sikap

13 J.D.Engel. 2018. Konseling Masalah Masyarakat. Yogyakarta:Kanisius. H. 2.

14 J. D. Engel. 2007. Konseling suatu Fungsi Pastoral. Salatiga: Tisara Grafika. H. 1. 
empati akan dapat memahami cara pandang dunia melalui perspektif klien. ${ }^{15}$

Engel mengemukakan bahwa konseling merupakan suatu upaya untuk memanusiakan sesama manusia. Dalam upaya memanusikan itulah, terkandung makna pemberdayaan yang menjadi tujuan utama suatu proses pendampingan dan konseling yang dilakukan. Dengan itu, konseling adalah suatu proses pertolongan yang membuat orang diberdayakan untuk hidup yang menghidupkan dan memanusiakan sesama manusia. Itu berarti konseling tidak sekadar membawa orang keluar dari keterpurukan dan penderitaan hidup, tetapi mengembangkan potensi-potensi yang dimiliki untuk memberdayakan dirinya dan orang lain, bahkan masyarakat. ${ }^{16}$ Dari pemahaman tersebut dapat disimpulkan bahwa konseling menjadi wadah pengembangan dan pemberdayaan terhadap potensi-potensi yang dimiliki oleh individu maupun kelompok untuk dapat melakukan perubahan baik untuk diri sendiri, orang lain maupun masyarakat. Perubahan yang dipromosikan untuk klien dapat menjadikan klien diberdayakan dan memberikan kontribusi yang baik dalam masyarakat.

Asumsi dasar yang mendasari masyarakat memimpin konseling bertolak pada berbagai bentuk pertolongan. Konseling masyarakat adalah bentuk pertolongan secara komprehensif, yang didasarkan pada kompetensi multicultural dan berorientasi keadilan sosial masyarakat. Karena perilaku manusia dipengaruhi oleh lingkungan, maka konselor masyarakat menggunakan strategi yang memfasilitasi perkembangan yang sehat dari

\footnotetext{
15 Nuzliah, Counseling Multikultural. Jurnal Edukasi Vol 2, Nomor 2, July 2016

16 J.D.Engel. 2018. Konseling Masalah Masyarakat. Yogyakarta:Kanisius. H. 2-3.
}

klien dan masyarakat. ${ }^{17}$ Konseling masyarakat seperti yang dikemukan oleh Lewis didalam Engel memberikan sebuah pemahaman bahwa sebagai konselor masyarakat harus memiliki ketrampilan dan strategis yang tepat dalam rangka memfasilitasi dan mendukung perkembangan klien yang sehat. Proses mendukung dan memfasilitasi klien bukan saja berdampak sehat bagi klien itu sendiri tetapi juga berdampak sehat pada masyarakat. Hal ini dikarenakan klien selalu dipengaruhi oleh lingkungan masyarakat dimana klien itu berada dan berinteraksi.

Kata masyarakat dipahamai secara berbeda, tergantung pada cara pandang orang bagaimana memahaminya. Lewis et al. didalam Engel menyadur pendapat Paisley yang merujuk defenisi masyarakat sebagai sistem yang memiliki kesatuan, kontinuitas, dan prediktabilitas. Individu, kelompok dan organisasi merupakan link bagi masyarakat. Masayarakat juga link individu untuk masyarakat lain, termasuk masyarakat yang lebih besar. Dengan demikian, masyarakat berfungsi sebagai media dimana individu dapat bertindak dan mentransformasikan norma. Dengan demikian, seorang individu menjadi milik lebih dari satu komunitas pada suatu waktu. Dengan itu, individu sebagai anggota masyarakat saling mempengaruhi secara langsung dan tidak langsung secara positif maupun negative. Asumsi berpikir seperti ini menjadi alasan mengapa pendampingan dan konseling masyarakat itu perlu. ${ }^{18}$ Dari pemahaman tersebut dapat disimpulkan bahwa masyarakat merupakan bagian yang tak terpisahkan dari relasi dan

\footnotetext{
${ }^{17}$ Lewis, Judith A, et.al, Community Counseling: A Multicultural-Social Justice Perspektive (USA,2011), 10

${ }^{18}$ P,O Paisley. 1996. Creating Community: Group Work and the Arts. Athens:GA.
} 
interaksi sosial yang dibangun oleh individu maupun kelompok. Penerapan norma-norma dalam masyarakat akan mempengaruhi pola pikir dan tindakan baik dari individu maupun kelompok. Individu maupun kelompok merupakan satu kesatuan yang tak terpisahkan dalam masyarakat yang saling berhubungan erat.

King didalam Engel menegaskan, sebagai anggota komunitas dalam lingkup nasional dan dunia, setiap individu harus mengembangkan hubungan yang sehat dan perasaan yang saling hormat menghormati. Konselor masyarakat diharapkan menemukan model konseling komunitas untuk membina kesehatan mental klien, dan mempromosikan masyarakat untuk lebih toleran, responsive, dan penuh perhatian. Untuk melakukan hal ini konselor masyarakat harus memiliki kompetensi multicultural agar bisa bekerja secara efektif dan etis, bersama orang-orang yang berasal dari kelompok yang beragam kompetensi dan latar belakang budaya. ${ }^{19}$ Dalam proses untuk mengembangkan hubungan yang sehat dan saling menghormati antara konselor dank lien diperlukan kompetensi multicultural yang harus dimiliki oleh seorang klien. Dengan berbagai latar belakang yang beragam dari klien, konselor harus mampu membangun kerja sama dan mampu mengenali konteks budaya dari klien sehingga proses konseling yang terjadi akan berjalan dan menghasilkan sesuatu yang baik untuk perubahan klien itu sendiri maupun perubahan lingkungan masyarakat.

Konseling masyarakat mempromosikan perubahan dan pertumbuhan,memberikan pedoman yang efektif untuk merencanakan dan melaksanakan program konseling masyarakat Walker yang produktif. Dengan itu asumsi yang mendasari konseling masyarakat abad ke-21 yaitu bahwa pembangunan manusia (individu) dan perilaku berlangsung dalam lingkungan masyarakat yang berpotensi memelihara, membatasi atau menghancurkan, pembangunan individu bersifat multicultural sebagai pusat konseling masyarakat, pengembangan individu dan masyarakat berhubungan erat. ${ }^{20}$ Jordan didalam Engel, dalam rangka meningkatkan hubungan dan memperbaiki perilaku klien yang bermasalah dalam masyarakat, diperlukan konseling budaya. Upaya ini bertujuan untuk menumbuhkan kekuatan, memulihkan dan menyehatkan, serta membebaskan dan memberdayakan klien yang bermasalah. Teoriteori konseling budaya lebih menekankan hubungan antara manusia dan lingkungan, dan telah menjadi prinsip utama konseling pada abad ke-21. Hal ini disebabkan oleh kekuatan lingkungan yang menjadi sumber belajar dan dukungan, untuk memenuhi kebutuahan terutama interaksi dengan orang lain. Di sisi lain, lingkungan juga dapat mempengaruhi dan mengerdilkan pertumbuhan dan membatasi perkembangan manusia. ${ }^{21}$

Berdasarkan pemikiran beberapa ahli diatas mengenai pengertian konseling dan konseling masyarakat maka, dapat disimpulkan bahwa konseling merupakan sebuah percakapan mendalam yang terjadi antara seorang konselor dengan klien. Proses percakapan tersebut didasari dengan rasa saling menghormati antara konselor dan klien yang mengarah pada proses kedamaian dan kebahagian hidup. Konseling yang berbasis

20 Lewis, Judith A, et.al. 2011. Community Counseling: A Multicultural-Social Justice Perspektive. USA:Brooks. H. 9

21 J,V.Jordan. 2010. Relational-Cultural therapy. Washingtong, DC: American Psychological Association. H. 99 
masyarakat merupakan suatu proses pertolongan yang membuat orang atau kelompok diberdayakan untuk memberikan kontribusi baik untuk diri sendiri, orang lain maupun masyarakat. Konselor masyarakat berperan sebagai agen perubahan yang mempromosikan pengembangan dan pembangunan manusia yang mengarah pada proses pemberdayaan hidup sehingga tercipta individu atau kelompok yang sehat, merata dan memiliki ketrampilan serta potensi diri yang dapat dijadikan sebagai modal untuk mempertahankan hidup ditengah arus realita sosial masyarakat yang beragam dan memiliki perbedaan.

\section{Konseling Social Justice}

Konseling masyarakat berorientasi pada keadilan sosial. Hal ini didasarkan pada asumsi, bahwa konselor masyarakat menggunakan sudut pandang yang luas untuk melihat klien dalam konteks lingkungan yang sehat, adil dan masyarakat yang merata. ${ }^{22}$ Ratts et al. mengklasifikasikan konseling social justice sebagai kekuatan kelima setelah multikultural dalam paradigma Konseling yang dianggap sebagai bentuk revolusioner dari pendekatan konseling. Pendekatan ini didasarkan pada keyakinan bahwa kondisi lingkungan mempengaruhi perkembangan manusia. ${ }^{23}$

Ratts Manivong.J dan Paul B. Pedersen juga menyinggung tentang konseling sosial justice yang juga mengandung aspek pemberdayaan baik seorang klien atau individu. Menurutnya, Tujuan social justice adalah memberdayakan semua individu, terlepas dari latar belakang mereka sehingga mereka dapat mengembangkan pengetahuan dan keterampilan

\footnotetext{
22 J.D.Engel. 2018. Konseling Masalah Masyarakat. Yogyakarta:Kanisius. H. 2-3.

${ }^{23}$ Manivong J. Ratts, Paul B Pedersen, Counseling for Multiculturalism and Social Justice, 28
}

untuk mencapai potensi penuh mereka. Konselor social justice menyadari bahwa masalah klien dapat dikaitkan dengan struktur yang menindas. Dengan demikian, baik konselor maupun klien secara aktif terlibat dalam proses mengeksplorasi dan mendapatkan pengetahuan tentang bagaimana struktur sosial mempengaruhi perkembangan klien. ${ }^{24}$ Dari pemahaman tersebut maka tujuan konseling sosial justice menginginkan sebuah upaya untuk bagaimana klien dapat diterima dalam lingkungan masyarkat dengan baik dan tidak lagi mengalami ketidaksetaraan dalam masyarakat. Klien memiliki kedamaian dan kebahagian hidup yang bebas dari penindasan dan diskriminasi. Kedamaian dan kebahagiaan yang tercipta, akan menumbuhkan rasa saling menghargai terhadap diri sendiri tetapi juga kepada orang lain. Dengan demikian akan terbuka hubungan atau relasi yang luas dan mendalam dengan orang lain yakni dengan menempatkan diri kita pada perasaan orang lain kita dapat mengetahui apa yang sedang digumuli. Keadilan sosial berkaitan dengan gagasan tentang masyarakat adil. Keadilan sosial adalah gagasan untuk menantang ketidakadilan dan menghargai kemanusiaan. Marsella mendefinisikan keadilan sosial sebagai "konteks sosial, terutama dalam masyarakat dan kondisi budaya yang mungkin membatasi atau menghilangkan kemungkinan adanya keadilan kolektif. ${ }^{25}$

Keadilan sosial berfokus pada tiga hal: Hak, Manfaat, dan Kebutuhan. Hak berfokus pada apa yang dipercaya bahwa masyarakat sebagai satu komunitas harus menyediakannya

${ }^{24}$ Manivong J. Ratts, Paul B Pedersen, Counseling for Multiculturalism and Social Justice, 28

${ }^{25}$ Llewellyn J. Cornelius dan Donna Harrington. 2014. ASocial Justice Approach to Survey Design and Analysis. New York : Oxford University Press. H. 7 
sebagai bagian dari menjadi anggota di dalam masyarakat tersebut. Manfaat berfokus pada bagaimana masyarakat memantau siapa yang harus menerima hak tersebut. Kebutuhan adalah basis atau kriteria yang digunakan untuk mendistribusikan sumber daya berdasarkan hak yang dimiliki individu. Proses konseling selalu mengarah pada akhir yang memiliki hasil yang baik. Mcleod menjelaskan ada tiga kategori hasil akhir konseling yakni resolusi, belajar, dan inklusi sosial. Pertama, Resolusi terhadap masalah sumber dalam hidup. Resolusi mencakup pencapaian pemahaman atau perspektif terhadap masalah tersebut, mencapai penerimaan pribadi terhadap permasalahan, dan mengambil tindakan untuk mengubah situasi yang merupakan sumber permasalahan. Kedua, belajar mengikuti konseling agar mendapat pemahaman, keterampilan, dan strategi baru yang membuat diri mereka dapat menangani masalah serupa dimasa yang akan datang. Ketiga, inklusi sosial konseling memberikan energi dan kapasitas personal sebagai seorang yang dapat memberikan kontribusi terhadap makhluk lain dan kepentingan sosial. ${ }^{26}$

Berdasarkan beberapa pemahaman diatas dapat disimpulkan bahawa konseling social justice selalu menekankan aspek keadilan dan kesetaraan hidup yang akan diperoleh oleh individu maupun kelompok. Interaksi dan realita sosial yang selalu dipenuhi oleh berbagai perbedaan baik dari segi budaya, strata sosial maupun tingkat ekonomi yang berbeda selalu menjadikan individu maupun kelompok sulit untuk dapat melakukan pembangunan dan pengembangan hidup. Individu maupun kelompok merasa terpinggirkan dengan berbagai

${ }^{26}$ John Mcleod. 2010. Pengantar Konseling, Teori dan Studi Kasus. Kencana. H. 17-18. realitas sosial yang menekan dan berbeda. Untuk itu konseling sosial justice menghadirkan sebuah perubahan yang mengarah pada prose pembangunan dan pengembangan hidup yang diberdayakan sehingga dapat memberikan kontribusi baik untuk diri sendiri, orang lain maupun masyarakat selain itu, hak, manfaat dan kebutuhan hidup dapat diperoleh dengan baik.

\section{Ritual}

Couldry (2005:60) memahami ritual sebagai suatu habitual action (aksi turuntemurun), aksi formal dan juga mengandung nilai-nilai transcendent. ${ }^{27}$ Victor Turner menjelaskan ritual sebagai sarana untuk mengungkapkan nilai-nilai budaya yang dimiliki oleh suatu kelompok masyarakat. ${ }^{28}$ Berdasarkan pemikiran yang dikemukan oleh Couldry dan Turner, maka dapat disimpulkan bahwa, ritual sebagai bagian dari tradisi yang dilakukan oleh kelompok dalam masyarakat yang diwariskan secara turun-temurun dari leluhur sampai dengan generasi masa kini. Proses pewarisan tradisi tersebut mengandung nilai-nilai budaya yang dijadikan sebagai patokan untuk bertindak dan membangun relasi sosial dalam masyarakat.

Menurut Turner dalam buku Ritual and Event, ritual sangat efektif sebagai wadah untuk mengekspresikan perasaan yang tertekan, cemas dan merasa terpinggirkan, dengan mengungkapkan Emosi ini sambil membiarkan perubahan terjadi, semua orang bisa kembali ke masyarakat baru. Masyarakat baru yang dimaksudkan disini adalah kehidupan masyarakat yang setara. Ritual memungkinkan ikatan dari

27 Couldry Nick. 2005. Media Ritual: Beyond Functionalims dalam Media Anthropology (Sage Publication)

${ }^{28}$ Victor Turner. 1969. The Ritual Process: Structure and Anti-Structure. New York: Cornel University Pres. H. 6 
sebuah komunitas. ${ }^{29}$ Dari pemahaman Turner dapat disimpulkan bahwa, ritual dijadikan sebagai wadah untuk individu maupun kelompok mengungkapkan ekspresi mereka sebagai individu yang merasa tertindas, terpinggirkan dengan berbagai realita sosial yang beragam dan berbeda. Proses pengungkapan perasaan tersebut juga merupakan bagian untuk mengembangkan dan memberdayakan potensi diri.

Sebagai sebuah nilai yang dihayati, kebudayaan diwariskan secara turun-temurun, dari satu generasi ke generasi. Proses pewarisan kebudayaan disebut sebagai proses enkulturasi. Proses enkulturasi berlangsung mulai dari kesatuan yang terkecil, yakni keluarga, kerabat, masyarakat, suku bangsa, hingga kesatuan yang lebih besar lagi. Proses enkulturasi ini berlangsung dari masa kanak-kanak hingga masa tua. Melalui proses enkulturasi ini, maka dalam benak sebagian besar anggota masyarakat akan memiliki pandangan, nilai yang sama tentang persoalan-persoalan yang dianggap baik dan dianggap buruk, mengenai apa yang harus dikerjakan dalam hidup bersama dan mengenai apa yang tidak harus dikerjakan. ${ }^{30}$

Berdasarkan pemahaman yang dikemukan oleh Abdul Aziz, dalam sebuah kebudayaan terdapat berbagai nilai yang terus dihayati baik oleh individu maupun kelompok dalam masyarakat. Proses penghayatan terhadap nilainilai budaya tersebut merupakan proses enkulturasi yang dilakukan secara turun-temurun. Pemikiran kolektif yang telah ada baik dalam diri

29 Franko Mark. 2007. Ritual and Event: Interdisclipinary Perspectives. New York: Routledge

30 Abdul Asis, "Nilai Budaya dalam Upacara Adat Mappogau Hanua di Karampuang, Kabupaten Sinjai, Provinsi Sulawesi Selatan, “ Jurnal Walasuji, Vol.6 Nomor 2 (Desember 2015): 384 masing-masing individu maupun kelompok, dalam keluarga, masyarakat, suku bangsa maupun kesatuan yang lebih besar. Pemikiran kolektif tersebut akan dijadikan sebagai sebuah patokan dan pandangan untuk bertindak dalam relasi sosial.

\section{HASIL DAN PEMBAHASAN}

\section{Ritual Musikal Totobuang Dikaji Dari Perspektif Konseling Masyarakat}

a. Pelaksanaan ritual musikal otobuang

Pelaksanaan ritual musikal totobuang dalam komunitas haur di Dusun Kusu-kusu Sereh, Ambon melahirkan makna dan nilai-nilai spiritual yang dapat dijadikan sebagai landasan hidup. Tradisi ritual musikal totobuang yang biasanya dilakukan dalam perkawinan adat, pelantikan raja, perayaan hari-hari besar gerejawi bahkan dalam perayaan hari-hari besar agama lain seperti perayaan ramadhan bagi agama islam memberikan makna dan nilai kerukunan yang dibangun dalam suasana kebersamaan yang tidak lagi terdapat perbedaan baik dari segi budaya, strata sosial, tingkat perekonomian maupun agama. Setiap anggota komunitas haur totobuang merasa diterima dalam realita sosial yang berbeda. mereka dapat memberikan kontribusi lewat ketrampilan dan potensi yang mereka miliki sehingga dapat menjadi sesuatu yang bermakna baik untuk diri sendiri, orang lain maupun masyarakat. Potensi diri yang dimiliki dan dikembangkan oleh komunitas haur juga memberi makna pemberdayaan ekonomi.

Hasil penelitian diatas selaras dengan pemikiran Engel yang mengatakan bahwa pemberdayaan sangat penting dan dibutuhkan oleh seorang klien atau individu dalam 
menghadapi permasalahan sosial. pengembangan terhadap potensi diri diberdayakan untuk hidup yang menghidupkan dan memanusiakan sesama manusia. Artinya bahwa proses konseling yang diberikan bagi klien bukan hanya sekedar membawa klien keluar dari penderitaan dan keterpurukan hidup tetapi mengembangkan potensi-potensi yang dimiliki untuk memberdayakan dirinya dan orang lain, bahkan masyarakat. $^{31}$ Individu maupun kelompok melaksanakan tradisi ritual musikal totobuang disamping untuk tetap mengembangkan dan melestarikan budaya lokal, proses pemberdayaan ekonomi menjadi hal utama dalam pelaksanaan ritual musikal totobuang.

b. Ritual musikal totobuang sebagai pewarisan dan pelestarian budaya lokal

Dalam perkembangan globalisasi, masuknya berbagai budaya atau tradisi dari luar seperti budaya barat membuat budaya lokal mengalami pergeseran makna serta pelaksanaan sudah jarang untuk dilakukan. Bagi individu maupun kelompok yang tetap dengan paradigm mereka untuk mempertahankan dan melestarikan budaya lokal tetap memegang erat makna pelestarian budaya lokal. Nilai-nilai budaya yang terkandung dalam budaya lokal dapat dijadikan sebagai sebuah landasan hidup yang berorientasi pada kebersamaan dan kedamaian hidup. Nilainilai budaya tersebut dihayati dan dijadikan sebagai pewarisan nilai-nilai luhur budaya lokal yang telah diteruskan dari leluhur sampai generasi masa kini. Hasil penelitian diatas selaras dengan pemikiran Turner yang mengatakan bahwa ritual sebagai sarana untuk mengungkapkan nilai-nilai budaya yang dimiliki

\footnotetext{
31 J.D.Engel. 2018. Konseling Masalah
} Masyarakat. Yogyakarta:Kanisius. H. 2. oleh suatu kelompok masyarakat. ${ }^{32}$ Nilai-nilai budaya yang terkandung dalam pelaksanaan ritual musikal totobuang dijadikan sebagai pedoman hidup bagi komunitas haur untuk membangunn relasi dalam masyarakat.

c. Ritual musikal totobuang sebagai wadah pengembangan dan pemberdayaan potensi diri

Konteks hidup masyarakat di Dusun Kusu-kusu sereh, Ambon saat ini bukan hanya terdiri dari penduduk asli akan tetapi ada pula penduduk dengan budaya yang lain atau pendatang. Penduduk asli dengan pendatang terjadi dalam hubungan perkawinan antara penduduk asli dengan pendatang, ada pula pendatang yang sudah lama menetap karena pekerjaan (perawat, polisi, TNI, Guru, PNS, dll). Dengan beragam perbedaan yang ada disamping perbedaan budaya, terdapat juga perbedaan strata sosial dan perbedaan tingkat perekonomian menghendaki relasi sosial yang dibangun seringkali mengalami gesekan atau bahkan tidak merata dan seimbang. Setiap individu maupun kelompok dengan berbagai karakteristik bahkan pandangan yang berbeda mengenai hidup sering membeda-bedakan individu maupun kelompok lain dalam relasi sosial. hal tersebut dikarenakan terdapat berbagai perbedaan yang telas dijelaskan sebelumnya. Pemikiran mereka juga terkait dengan kontribusi yang diberikan dalam masyarakat.

Ritual musikal totobuang hadir dan memberi makna hidup bagi komunitas haur untuk dapat membangun relasi sosial yang seimbang dan merata. Memberi sebuah makna bagi setiap anggota komunitas haur bahwa dengan potensi

32 Victor Turner. 1969. The Ritual Process: Structure and Anti-Structure. New York: Cornel University Pres. H. 6 
dan kemampuan yang mereka miliki dapat juga memberikan kontribusi baik untuk diri sendiri, orang lain maupun masyarakat. Dengan potensi dan ketrampilan yang dimiliki dapat meningkatkan perekonomian keluarga yang lebih berkualitas. Selain itu proses pelaksanaan ritual musikal totobuang ini juga dilakukan dalam perayaan ramadhan oleh kaum muslim. Sebagai respon dari membangun dan menjaga ikatan persaudaraan dalam masyarakat, komunitas haur turut serta dalam berkolaborasi dengan musik islami yang memberi makna harmonisasi musik sebagai wadah pemersatu dan pengikat tali persaudaraan antar umat beragama.

Dalam pelaksanaan ritual musikal totobuang terdapat nilai-nilai spiritual yang dapat dijadikan sebagai upaya pengembangan dan pemberdayaan potensi diri yang mengarah pada kesetaraan dan kesejahteraan dalam msayarakat.

Pertama, ritual musikal totobuang memberi makna kerukunan dalam membangun kesetaraan sosial dalam masyarakat. Dalam proses pelaksanaan ritual musikal totobuang biasanya dilakukan dalam acara perkawinan adat, pelantikan raja bahkan dalam perayaan ramadhan bagi kaum muslim. Ritual musikal totobuang menjadi musik pemersatu dengan alunan kegembiraan yang mempersatukan semua orang yang hadir bahkan orang-orang yang beragama lain. Selain itu hal baru yang juga ditemukan dalam proses ritual musikal totobuang yaitu setiap anggota dari komunitas haur totobuang yang merasa terpinggirkan atau tidak percaya diri karena strata dan tingkat ekonomi yang berbeda merasa dipersatukan dalam ikatan kebersamanaan bersama dengan semua orang yang hadir.

Kedua, ritual musikal totobuang melahirkan potensi diri. Konteks masyarakat di Dusun kusu-kusu sereh yang beragam dengan perbedaan baik dari segi budaya, strata sosial maupun tingkat perokonomian yang berbeda jauh, membuat anggota dari komunitas haur merasa terpinggirkan dan tidak diterima atau dapat dikatakan mereka mengalami krisis identitas diri akibat dari realita sosial yang ada. Sebagai upaya untuk penerimaan diri yang memberi penghargaan terhadap diri maka ritual musikal totobuang hadir sebagai bagian pencapaian dari integritas diri komunitas haur dalam masyarakat. Pencapaian dari integritas diri inilah yang mampu mengembangkan dan memberdayakan potensi diri yang ada pada mereka. Mereka mampu menampilkan dan memberikan sesuatu yang penting melalui ritual musikal totobuang. Ketiga, ritual musikal totobuang melahirkan ekonomi kreatif sebagai akibat dari krisis ekonomi yang terjadi dalam komunitas haur. Mengutip dari Cetak Biru Ekonomi Kreatif 2025, ekonomi kreatif merupakan suatu penciptaan nilai tambah (ekonomi, sosial, budaya, lingkungan) berbasis ide yang lahir dari kreativitas sumber daya manusia (orang kreatif) dan berbasis pemanfaatan ilmu pengetahuan, termasuk warisan budaya dan teknologi. ${ }^{33}$

Ritual musikal totobuang sebagai pewarisan budaya lokal mampu dijadikan sebagai wadah untuk membentuk ekonomi kreatif yang bersumber dari ide atau gagasan yang kreatif dari sumber daya manusia itu sendiri. Sumber daya manusia yang dimaksudkan disini berasal dari setiap anggota komunitas haur totobuang. Mereka mampu mementaskan permainan musikal totobuang sekaligus juga membuat totobuang yang memiliki nilai jual yang tinggi. Berdasarkan hasil yang didapat dalam penelitian, pementasan

33 Agus Pascasuseno. 2014. Ekonomi Kreatif: Kekuatan Baru Indonesia Menuju 2025. Bedah Cetak Biru Ekonomi Kreatif: Yogyakarta. 
ritual musikal totobuang terjadi dalam berbagai bentuk acara maupun kegiatan. Harga atau tarif yang didapatkan dari pementasan tersebut berkisar antara Rp 3.000.000-Rp 5.000.000 dan harga jual untuk pembuatan totobuang buang sendiri yaitu Rp 35.000.000. Tifa sebagai alat musik yang selalu dikolaborasikan dengan totobuang juga memiliki nilai jual yang tinggi. Harga jual dari tifa sendiri sangat bervariasi tergantung besar atau kecil yang berkisar antara Rp 300.000-Rp 600.000. ${ }^{34}$ Dengan adanya pementasan ritual musikal totobuang tersebut berbagai potensi yang ada dari setiap anggota dalam komunitas haur totobuang, dapat dikembangkan dan diberdayakan sehingga memiliki kesetaraan dan kesejahteraan hidup dalam masyarakat.

Keempat, ritual musikal totobuang memberi makna pengembangan diri bagi komunitas haur untuk terus melakukan inovasi diri. Inovasi merupakan Suatu transformasi dari ide atau gagasan dengan dasar kreativitas dengan memanfaatkan penemuan yang sudah ada untuk menghasilkan suatu produk ataupun proses yang lebih baik, bernilai tambah, dan bermanfaat. ${ }^{35}$ Dengan melakukan pementasan ritual musikal totobuang, kreativitas setiap anggota komunitas haur terus dikembangkan dan diberdayakan sehingga terus memiliki nilai tambah yang tinggi dan bermanfaat baik itu diri sendiri, orang lain maupun masyarakat.

Kelima, ritual musikal totobuang memberi makna pemberdayaan hidup. Dengan adanya pelaksanaan ritual musikal totobuang tersebut, ketrampilan dan potensi diri dari setiap

\footnotetext{
34 Hasil wawancara dengan bapak O. Salakay (ketua komunitas haur), 7 Juni 2018

${ }^{35}$ Rochmat, A. Purnomo. 2016. Ekonomi Kreatif : Pilar Pembangunan Indonesia. Surakarta: Ziyad Visi Media. H. 9
}

anggota komunitas haur dapat diberdayakan dan dikembangkan sehingga dapat memberikan kontribusi baik untuk diri sendiri, orang lain maupun masyarakat. Realita sosial yang tidak merata yang menghendaki setiap individu maupun kelompok harus mampu berjuang dan mengembangkan potensi diri dalam rangka meningkatkan kualitas hidup yang lebih bermutu atau dapat dikatakan pengembangan potensi diri bertujuan untuk pemenuhan kebutuhan ekonomi.

\section{KESIMPULAN}

Bagian akhir dari jurnal ini, penulis memberikan kesimpulan yang merupakan jawaban dari rumusan masalah yaitu: (1) Pelaksanaan dan asal-usul ritual musikal totobuang melahirkan paradigma berpikir yang kontekstual dari suatu individu maupun komunitas dalam masyarakat yang menjadikan ritual musikal totobuang sebagai bagian dari pewarisan nilai-nilai budaya lokal yang masih terus dijaga, dilestarikan dan dikembangkan oleh generasi ke generasi. Pengembangan akan budaya lokal ini dapatkan juga dijadikan sebagai wadah pemberdayaan ekonomi bagi komunitas. Nilainilai spiritual yang terdapat dalam ritual musikal totobuang melahirkan sebuah landasan filosifis yakni “Hidup yang Memanusiakan”. Hidup yang mampu memberdayakan diri sendiri, orang lain maupun masyarakat.

Selanjutnya (2) nilai-nilai spiritual ini dibentuk dari landasan filosofis hidup yang mampu menciptakan kesetaraan dam keseimbangan dalam masyarakat, yang juga menjadikan budaya lokal sebagai warisan leluhur yang harus terus dijaga, dilestarikan dan dikembangkan sebagai bagian dari proses pemberdayaan terhadap potensi diri yang 
mengarah pada ekonomi kreaktif, inovasi diri dan kesejahteraan hidup; (3) Ritual musikal totobuang dijadikan sebagai resolusi untuk pemberdayaan hidup yang damai dan sejahterah yang mendorong setiap individu maupun kelompok untuk terus mengembangkan potensi diri dan melestarikan budaya lokal sebagai warisan leluhur; dan (4) Ritual musikal totobuang sebagai pendekatan konseling berbasis masyarakat yang bekerja untuk mempromosikan perubahan positif dalam sistem masyarakat yang mempengaruhi kesejahteraan hidup dari individu maupun kelompok.

\section{DAFTAR PUSTAKA}

Adeney, Bernard T. 2000. Etika sosial Lintas Budaya. Yogjakarta: Kanisius.

Abdul Asis, "Nilai Budaya dalam Upacara Adat Mappogau Hanua di Karampuang, Kabupaten Sinjai, Provinsi Sulawesi Selatan, " Jurnal Walasuji, Vol.6 Nomor 2 (Desember 2015)

Agus, Pascasuseno. 2014. Ekonomi Kreatif: Kekuatan Baru Indonesia Menuju 2025. Bedah Cetak Biru Ekonomi Kreatif: Yogyakarta.

Cornelius Llewellyn J, Donna Harrington. 2014. ASocial Justice Approach to Survey Design and Analysis, New York : Oxford University Press.

Creswell, John W. 2013. Research Design: Pendekatan Kualitatif, Kuantitatif dan Mixed. Yogyakarta: Pustaka Pelajar.

Depdiknas. Kamus Besar Bahasa Indonesia, Edisi Ketiga, Jakarta: Penerbit Balai Pustaka, 2003

Engel, Jacob. D. 2018. Konseling Masalah Masyarakat. Yogyakarta: Kanisius.
Engel, Jacob. D. 2016. Pastoral dan Kebutuhan Dasar Konseling. Jakarta: Gunung Mulia.

Engel, Jacob. D. 2007. Konseling Suatu Fungsi Pastoral. Salatiga: Tisara Grafika.

Franko, Mark. Ritual and Event. New York: Routledge, 2007

Jordan, J.V. Relational-cultural Therapy. Washington, DC: American Psychological Association, 2010

King, M.L. 1963. Strength to Love. New York: Walker.

Lewis, J.A.,Lewis, Michael D., Daniel, Judy A., D'Andrea, Michael J. Community Counseling: A Multicultural-Social Justice Perspective, Fourth Edition. Brooks/Cole 20 Davis Drive Belmont, USA, 2011

McLeod, John. 2010. Pengantar Konseling, Teori dan Study Kasus. Kencana.

Nuzliah, Counseling Multikultural. Jurnal Edukasi Vol 2, Nomor 2, July 2016

Paisley, P.O. Creating Community: Group Work and the Arts. Presentation Made at the Annual Meeting of the Association for Specialists in Group Work. Athens: GA, 1996

Ratts, Manivong. J and Paul B. Pedersen. 2014. Counseling for multiculturalism and social justice; integration, theory, and application. Amerika: American Counseling Assiciation.

Rochmat, A. Purnomo, Ekonomi Kreatif : Pilar Pembangunan Indonesia, Surakarta: Ziyad Visi Media, 2016

Sugiyono. 2012. Metode Penelitian Kombinasi. Bandung: Alfabeta.

Sugiyono. 2013. Metode Penelitian Kuantitatif, Kualitatif dan $R \& D$. Bandung: Alfabeta. 
Sukalele, Daniel "Pemberdayaan Masyarakat Miskin di Era Otonomi Daerah", dalam

wordpress.com/about/pemberdayaanmasyarakat-miskin-di-era-otonomidaerah diakses tgl. 27 Agustus 2018

Surakhmad, Winarno. 1985. Pengantar Penulisan Ilmiah: Dasar Metode dan Teknik, Bandung: Tarsito.

Turner, Victor. 1969. The Ritual Process: Structure and Anti-Structure. New York: Cornel University Press. 